\title{
Exploring the causes and consequences of director overboardedness in an emerging market
}

\author{
Nadia Mans-Kemp ${ }^{1} \cdot$ Suzette Viviers $^{1} \cdot$ Sian Collins $^{1}$
}

Received: 12 October 2018/Published online: 29 October 2018

(C) The Author(s) 2018

\begin{abstract}
Scholars and shareholder activists have raised concerns about directors serving on multiple boards simultaneously. Semi-structured interviews were conducted with 10 experienced diverse South African directors to investigate the causes and consequences of overboardedness. Interviewees identified the limited talent pool and board diversity targets as the main causes of overboardedness (or interlocking as it is also called). In line with the busyness hypothesis, poor meeting attendance by overboarded directors was highlighted by some participants. However, others claimed that director interlocking could offer invaluable access to social networks and resources, lending support to the experience hypothesis. Director busyness should hence be considered on a case-by-case basis.
\end{abstract}

Keywords Agency theory - Busyness hypothesis - Director interlocking · Director overboardedness - Experience

hypothesis $\cdot$ Resource dependence

\section{Introduction}

Being a director of a public or private company could be regarded as a double-edged sword. The benefits, such as prestige and substantial remuneration, should be weighed against the potential for reputational damage, time commitments and the duties accompanying each board position (Katz and McIntosh 2016). The balancing act becomes

Nadia Mans-Kemp

nadiamans@sun.ac.za

1 Department of Business Management, Stellenbosch University, Private Bag X1, Matieland 7602, South Africa more complex when individuals serve on multiple directorates simultaneously (Oehmichen et al. 2017; Kaczmarek et al. 2014). A board of directors is not only responsible for setting the company's strategic direction, but it should also ensure that managers implement the strategy in an efficient and ethical manner.

The effectiveness of directors' monitoring role was questioned after the 2008 global financial crisis (Hill and McDonnell 2013). Much of the criticism stemmed from shareholders who argued that board members should have adopted a more active oversight role on their behalf. An increasing number of shareholders and other financiers started to interrogate boards and objected to directors who held multiple board positions, claiming that they might not be able to effectively fulfil their manifold roles (Orol 2016; Ferris et al. 2003). The term "overboardedness" refers to directors who serve on too many boards at the same time (Harris and Shimizu 2004). Although there is not a generally accepted guideline for the number of board positions that is likely to result in overboardedness, previous authors suggested that three or more outside (external) board positions could be regarded as excessive (Lee and Lee 2014; Fich and Shivdasani 2006).

Two schools of thought have emerged to explain the consequences of director overboardedness or interlocking as it is also called. The experience hypothesis postulates that multiple directorships may result in directors gaining invaluable experience and access to vast social networks and resources (Clements et al. 2015; Carpenter and Westphal 2001). In contrast, the busyness hypothesis suggests that directors might become overcommitted if they serve on several boards at the same time (Jiraporn et al. 2009b; Fich and Shivdasani 2006).

The main consequences of directors being overextended include insufficient meeting attendance and limited 
monitoring ability. The two hypotheses are not necessarily competing. The disadvantages of busyness might be offset by the benefits associated with experience. The dominant effect, as well as the associated benefits and costs, is influenced by corporate characteristics such as company size and the industry in which the company operates (Clements et al. 2015).

Research shows that directors not only tend to serve on more than one board, but that their time commitments to each of these boards are also rapidly increasing (Orol 2016; National Association of Corporate Directors 2015). In the United States (US), for instance, directors committed approximately $248 \mathrm{~h}$ to board matters in 2015 compared to $190 \mathrm{~h}$ in 2005, reflecting an increase of more than $30 \%$. On average, a US director serves on approximately five boards simultaneously, which include boards of public, private and non-profit companies (Orol 2016; National Association of Corporate Directors 2015). To address the adverse effects of overboardedness, more than $75 \%$ of S\&P 500 companies have recently limited the number of additional directorships. The majority of these companies capped the number of directorships at four or five (Spencer Stuart 2017)

Overboardedness is also gaining attention from proxy advisors such as the Institutional Shareholder Services Inc. (ISS 2017). This proxy advisor attends to a director's categorisation as either an executive or a non-executive director when offering advice on overboardedness to US asset owners and asset managers. While executive directors are involved in the day-to-day management of a firm, nonexecutive directors are not full-time employees. They are supposed to bring independent judgement to board-level decisions (Institute of Directors in Southern Africa (IoDSA) 2009). The ISS (2017) regards non-executive directors as overboarded if they serve on more than five boards of public companies at the same time. The ISS furthermore recommends that chief executive officers should not serve on more than two outside public boards at the same time. In the United Kingdom (UK), the governance code recommends that an executive director should not hold more than one non-executive position in a Financial Times Stock Exchange 100 company (Financial Reporting Council 2016). Listed companies are required to implement the code on a "comply or explain" basis.

As can be seen, the phenomenon of overboardedness has mainly been investigated by researchers in developed markets such as the US (e.g. Lamb 2017; Roudaki and Bhuiyan 2015; Jiraporn et al. 2009b; Fich and Shivdasani 2006; Kiel and Nicholson 2006; Mizruchi and Stearns 1988). Recently, a few studies on director overboardedness have also been published in emerging markets, notably in India (Jackling and Johl 2009; Sarkar and Sarkar 2009; Ghosh 2007) and Malaysia (Haniffa and Hudaib 2006).
Despite having one of the best developed corporate governance frameworks in the world, there are no clear guidelines on director overboardedness in South Africa. This emerging country provides an interesting case study in that there has been significant pressure on companies post1994 to transform the racial and gender composition of their boards. However, given the limited pool of female and black candidates, concerns have been raised about directors being too busy to perform their duties effectively (Mans-Kemp and Viviers 2015). Anecdotal evidence suggests that the busyness hypothesis prevails in South Africa as far as diverse candidates are concerned. This is evident from shareholder activists complaining about poor meeting attendance, particularly among diverse directors (Barron 2018; Kabi 2015; Barry 2014). Given that the country has a limited number of eligible board candidates, over-utilisation of the talent pool poses a considerable challenge to nomination committees (Inoxico 2013).

The topic of overboardedness has, however, only recently received scholarly attention in South Africa. Williams et al. (2016) considered the density of director inter-connectedness among the 40 largest companies listed on the Johannesburg Stock Exchange (JSE), while Chiranga and Chiwira (2014) examined the relationship between overboardedness and the financial performance of selected JSE-listed firms. In 2013, the African data provider Inoxico (2013) computed a so-called Director Singularity Index (DSI) to reflect the number of directorships held by directors serving on the boards of 360 JSE-listed firms. The DSI highlighted the potential risks posed by director interlocking.

Given limited research, the authors of the current study set out to investigate the causes and consequences of director overboardedness in South Africa. While previous authors mainly applied positivistic approaches, this study was conducted from the perspective of the directors themselves by conducting semi-structured interviews to obtain their personal views on director overboardedness. The findings of this study will hopefully shed more light on the applicability of the busyness hypothesis in the local context. Unless nomination committees have a better understanding of the consequences of overboarded directors, companies are likely to face more criticism from shareholders and the public at large.

The following literature review centres on the phenomena of director interlocking and overboardedness. Thereafter, the qualitative research design and methodology are explained. Based on the findings, recommendations are offered to companies, directors, nomination committees and shareholders. Suggestions for future research are also provided. 


\section{Director interlocking and overboardedness}

Director interlocking refers to the practice of board members who serve on the boards of multiple corporations (Bohman 2010). The experience hypothesis suggests that director interlocking could offer several advantages. However, if a director serves on an excessive number of boards, he/she might become overboarded, which has led to the term "overboardedness". The busyness hypothesis, on the other hand, relates overboardedness to several negative outcomes. These two hypotheses are explored in more detail next.

\section{The experience hypothesis}

According to the experience (or reputational capital) hypothesis, directors can gain invaluable experience and enhance their social connections by serving on several boards at the same time (Clements et al. 2015; Ferris et al. 2003). This hypothesis relates to the resource dependence theory that is based on the principle that organisations engage in transactions with other entities to acquire resources, such as capital, material and labour. Companies aim to enhance their bargaining position in resource-related transactions, inter alia by developing links to other organisations (Hillman et al. 2000; Pfeffer and Salancik 1978).

Director interlocking offer several advantages to companies and directors. By enlarging a firm's social network, resources may become more accessible (Kim and Kim 2015; Carpenter and Westphal 2001). Field et al. (2013) acknowledged that overboarded directors are often more experienced and better connected to influential people in the industry compared to their counterparts who serve on fewer boards. Furthermore, multi-boarded directors' experience and contacts make them excellent advisors. Proponents of the experience hypothesis thus claim that multiple directorships are a sign of a "director's quality", as the number of board positions is related to the extent of an individual's reputational capital (Clements et al. 2015). Nomination committees also tend to view interlocked directors as "high-quality" individuals and therefore invite them to serve on even more boards (Ferris et al. 2003).

Three factors that influence the number of board invitations to a director have been identified by Ferris et al. (2003). These authors found that directors who attract the most attention have typically served on the boards of big companies, companies with large boards and companies with sound financial performance. They ascribed their findings to the reputational effect. Several authors who found a positive relationship between overboardedness and financial performance (e.g. Lamb 2017; Lee and Lee 2014;
Chen 2008; Harris and Shimizu 2004) attributed their results to the experience hypothesis and a firm's degree of resource dependence.

Chen (2008) postulated that non-executive directors holding multiple directorships could have different implications for boards, depending on the boards' monitoring and advising needs. Non-executive directors holding more than two directorships tended to be better advisors than monitors. Lee and Lee (2014) documented a positive association between company value (as measured by Tobin's Q) and multiple directorships in firms where a high degree of monitoring is required. These are typically large companies and those owning many intangible assets. Interlocked directors can offer access to several points of reference when advice is required.

The categorisation of directors as executives or nonexecutives should be taken into account when assessing the impact of overboardedness (Sarkar and Sarkar 2009). These authors reported that while multiple directorships for executive directors were negatively related to firm performance, multiple directorships by independent directors were positively related with the performance of 500 large listed manufacturing companies in India. They used the return-on-assets ratio, market-to-book ratio, Tobin's $\mathrm{Q}$ and net-value-added-to-assets to measure company performance. They furthermore reported that the multi-boarded independent directors did not miss a considerable number of board meetings.

The number of outside board positions could have a substantial impact when assessing both the experience and busyness hypotheses. Iturriaga and Rodríguez (2014) reported that for low levels of multiple directorships, the experience effect seemed to prevail. These authors found that Spanish directors who served on a limited number of boards enhanced their skills and had more incentives to perform directorial duties with a resulting positive impact on a firm's financial performance. However, after a threshold of four boards was reached, most directors became "overwhelmed". Kaczmarek et al. (2014) asserted that excessive interlocking is likely to compromise directors' commitment and attention and that the effects of the busyness hypothesis might then arise.

\section{The busyness hypothesis}

The busyness hypothesis postulates that if directors become overcommitted, they might become less effective corporate monitors (Clements et al. 2015). The hypothesis is linked to the agency theory. In the light of the separation between ownership and control, the agency theory suggests that conflict of interest might arise between shareholders and managers (Jensen and Meckling 1976). In an attempt to curb agency conflict and to limit resultant agency costs, 
considerable focus is placed on the monitoring role of the board (Haniffa and Hudaib 2006).

Individuals who hold multiple directorships simultaneously face severe time constraints (Ahn et al. 2010). As a result, their reduced attention may affect their ability to provide sound advice. Researchers have furthermore argued that overboarded directors tend to miss a disproportionate number of board meetings (Chiranga and Chiwira 2014; Jiraporn et al. 2009a).

Authors who reported a negative association between overboardedness and a company's financial performance ascribed this relationship to the busyness effect (Clements et al. 2015; Fich and Shivdasani 2006). Kaczmarek et al. (2014), for example, showed that excessive interlocking occurring at large financial and utility firms in the UK compromised directors' attention and had a negative impact on these firms' financial performance. The financial performance of these firms was measured by Tobin's $Q$ and market-to-book ratio over a 10 -year period.

Fich and Shivdasani (2006) reported similar results for busy non-executive directors in the US. They warned that if non-executive directors held three or more board positions they could become overcommitted and their monitoring ability could decrease. Liu and Paul (2015) reported that the negative effects of busyness are even more pervasive for executive directors than for non-executive directors.

The relationship between corporate governance and the social networks of 1600 directors of selected listed German companies between 2003 and 2006 was examined by Andres et al. (2013). These authors found that companies with well-connected directors experienced lower marketbased financial performance (as measured by Tobin's Q) and paid their executives a higher salary than companies with fewer interlocked directors. They ascribed their findings to the poor monitoring ability of directors being too embedded in social networks. They added that possible overboardedness should be considered prior to the nomination of board candidates. In this respect, nomination committees have a considerable influence on the composition of directorates (Ruigrok et al. 2006).

\section{The relationship between board diversity and overboardedness}

As explained earlier, director overboardedness can be ascribed to several factors, including the size of the company, and the benefits of directors gaining prestige and access to social networks. Pressure on companies to improve their board diversity may also play a role, as companies are increasingly required to diversify their directorates' composition. In Norway, for instance, listed companies are obliged to appoint female directors to reach a quota (Ahern and Dittmar 2012), while the UK legislator has set voluntary targets to improve female board representation (Davies 2015).

Although JSE-listed companies are not legally obliged to appoint female and black directors, the King III Report encouraged boards to consider whether their size and demographic characteristics (notably race, gender, age and expertise) make them effective (IoDSA 2009). The latest King Report highlights the need for governing bodies to set and disclose their progress towards voluntary, companyspecific targets for board diversity in respect of ethnicity and gender (IoDSA 2016).

Given the limited talent pool, eligible female and black directors are invited to serve on several boards simultaneously. As a result, they may become overboarded (Jackling and Johl 2009). Sarkar and Sarkar (2009) added that the relatively high permissible limits on multiple directorships in India could be driven by supply constraints in the managerial labour market. Roudaki and Bhuiyan (2015) also attributed the large number of interlocked directors in New Zealand to a shortage of qualified and independent directors.

Scholars such as Kaczmarek et al. (2014) posited that board diversity could act as a moderator of the interlocking-firm-performance relationship, particularly when trying to reconcile the busyness and experience hypotheses. These authors also asserted that there is considerable potential for the dissemination of ideas when companies are intertwined. Knowledge exchange is partly facilitated by the level of and changes in board diversity. Diverse directors could make valuable contributions to boards. They should, however, be aware of the risks of becoming "over-stretched" by serving on too many boards simultaneously.

\section{Research design and methodology}

It is evident from the literature review that, although director overboardedness can be regarded as a managerial challenge, multiple directorships can also offer several advantages to directors and the companies where they serve. Given limited academic enquiry into the topic of director overboardedness in South Africa, an exploratory study was undertaken. Primary data were collected by conducting semi-structured interviews with 10 directors of JSE-listed companies. The researchers used their judgement to identify suitable research participants. These participants' eligibility was measured in terms of experience, categorisation (executive or non-executive director), age, ethnicity, gender and type of industry in which their respective companies conducted business.

The interview guide consisted of open-ended questions. Biographic information was requested followed by 
questions related to the causes and consequences of director overboardedness. Both the advantages and disadvantages of the busyness and experience hypotheses were encapsulated in the questions. Seven interviews were conducted in person and three via Skype between June 2017 and April 2018. The interviews were voice-recorded and then transcribed. Data analysis comprised a descriptive overview of the sample's characteristics, followed by a thematic analysis (Braun and Clarke 2006). Thematic analysis is commonly used to identify themes when comparing the responses gathered from interviews.

To protect the anonymity of the interviewees, an overview of the sample's demographic characteristics is provided, instead of offering details on each individual's demographic profile. The least experienced interviewee had been a director for 8 years, whereas the most experienced interviewee had served on the boards of JSE-listed companies for 44 years. The sample included an equal number of executive and non-executive directors. The participants' ages ranged from 34 to 69 . An equal number of black and white participants, and males and females were included in the sample.

The interviewees served on the boards of companies doing business in the industrial, consumer goods, consumer services, financial, technology and telecommunications sectors. On average, the interviewees served on approximately two boards of listed and three boards of unlisted entities, based on their board positions at the time when the interviews were conducted. The maximum number of board positions that an interviewee held at the same time was four listed companies and nine unlisted companies. The interviewees simultaneously served on between one and five board committees.

Pertaining to credibility and conformability, the questions posed were based on academic sources reported in the literature section and the findings were linked to the literature where applicable. The authors aimed to ensure that the participants' views were accurately reflected by reading through the interview transcriptions several times. Prior to the research, ethical clearance was obtained from the university's research ethics committee.

\section{Findings and discussion}

Six themes were identified. These themes are discussed in the following sections.

\section{Awareness of overboardedness in the South African context}

The majority of participants were familiar with the phenomenon of director overboardedness or interlocking.
Definitions provided by participants included "overboardedness occurs when directors sit on numerous boards and are unable to properly fulfil their duties"; "directors who are spread too thinly due to taking on too many board responsibilities"; and "when individuals are represented on too many boards and it then has a negative impact on their effectiveness". From these definitions, it was evident that the interviewees had fairly negative connotations of the phenomenon.

Several participants perceived some local directors as being overboarded. Williams et al. (2016) confirmed that the South African director network includes several individuals who serve on multiple boards at the same time. Three participants, however, cautioned that the term "overboardedness" should not be generalised by implying that all directors with more than one board position are overboarded. According to them, overboardedness should be assessed on a case-by-case basis. In support of this view, one interviewee stated that "if you serve [on the board] of a listed company and [its] committees, it takes up time but having said that, some people do not do anything except sit on boards for a living".

Another participant added that some directors are capable of dealing with more responsibilities than others. When evaluating overboardedness, attention should thus be given to a director's number of board positions at both listed and unlisted companies, and their ability to manage the associated responsibilities. These views relate to the literature (Clements et al. 2015; Lee and Lee 2014) which states that corporate context and individual circumstances should be taken into account when assessing overboardedness.

\section{Possible causes of overboardedness}

The second theme that emerged from the data analysis centred on the possible causes of directors overboardedness. Three possible reasons were identified in the local context, namely the limited pool of eligible board candidates, board transformation requirements and financial rewards.

According to the data provider Inoxico (2013), the overutilisation of the relatively small pool of skilled directors is a real challenge in South Africa. Several participants in this study also emphasised the country's limited talent pool as contributing to interlocking, especially pertaining to eligible non-executive directors. One participant pointed out that "everyone is drawing from the same small pool and when you ask a company if they would mind overboardedness versus having the right skills and experience on the board, they would generally rather deal with overboardedness". In New Zealand, Roudaki and Bhuiyan (2015) 
also ascribed overboardedness to a shortage of qualified, independent directors.

A participant hinted that it is "difficult to put a director in a listed entity as a first-time board appointment". Such directors often require extensive development. This participant added that there were companies that were indeed appointing and developing inexperienced directors. According to this participant, the pool was thus growing, albeit at a slow pace. Researchers in emerging markets likewise suggested that a limited talent pool might contribute to overboardedness (Jackling and Johl 2009; Sarkar and Sarkar 2009).

One director remarked that "if you follow the careers of most of the sought-after diverse candidates, it is amazing to see how their number of boards grows". An interviewee, who believed that the local talent pool was "very small", explained that this pool historically comprised a majority of mature white males "who served on several boards and who all knew each other". However, according to him, the dynamics was changing to include diverse candidates, especially "younger black females". Research by MansKemp and Viviers (2015) confirms that the number of black and female directors serving on the boards of JSElisted companies has increased significantly since 2002 . Further changes in board ethnicity and gender diversity can be expected in the light of the King IV Report's recommendations on board diversity (IoDSA 2016).

One director remarked that the incorporation of board diversity requirements in the JSE listing requirements (JSE 2017) left public companies with no other option than to change. A counterpart, however, warned that "imposing board diversity agendas can be to the detriment of skills if unqualified [incompetent] individuals are hired only to meet diversity requirements".

An interviewee noted that black females were especially in high demand as they could contribute to both board ethnicity and gender targets: "As soon as you know of one [defined by the participant as a black female] and she is competent, the news spreads like wild fire and she gets appointed to nearly every board". Another interviewee warned that experienced female directors would become even more overboarded unless more females were trained and more board opportunities were offered to increase the talent pool.

Participants' views were gauged on the phenomenon of so-called token director appointments. In line with the findings of Nyirenda (2010), a number of participants acknowledged that certain board appointments were made based on ethnicity or gender, but that this practice was decreasing. Other participants, however, remarked that inexperienced, diverse individuals were sometimes regarded as tokens when appointed to their first board. The role of the nomination committee to assist and develop such directors was emphasised.

An alternative view was raised, namely that competition among companies might limit the number of board positions held by sought-after diverse candidates. One of the interviewees remarked that "in most industries you have a few significant players and as soon as you are associated with one of those groups you are disqualified from being involved in other groups. So it is not just the limited pool, it is [also] the competitive situation that you are in".

In line with the literature, notably Kaczmarek et al. (2014) and Hafsi and Turgut (2013), several interviewees recommended that other board diversity elements such as experience, educational background and age should also be taken into account in addition to ethnicity and gender when directors are appointed. One participant remarked that an age differential was of particular importance in certain areas, and that "you might need to stay up to date in fastmoving industries such as technology". This view is supported by Barrett (2017) who found that information technology firms had, on average, the youngest directors of all considered S\&P 500 companies.

Reference was also made to the monetary benefits associated with holding multiple board positions, as one participant remarked: "Some people take as many [directorships] as you offer them because of the money". This view concurs with Andres et al. (2013) who found that substantial monetary benefits encourage directors to accept several board positions. In addition, the local media has focused on the controversial topic of excessive executive compensation as it has been revealed that executives earned almost 500 times more than the average South African employee (Lu and Melin 2016).

Another interviewee, however, claimed that not all directors are driven primarily by financial rewards. He indicated that some individuals accepted more non-executive positions "to stay connected and to coach and mentor younger directors". The support of a seasoned mentor could enable a promising, diverse candidate to develop the perspectives and vision that are needed to reach their full potential (Clutterbuck and Megginson 1999).

\section{Directors' views on the experience hypothesis}

Several participants mentioned benefits of overboardedness that could be linked to the experience hypothesis and resource dependence theory. One mentioned that multiple board memberships indeed "help[ed] with efficiency and familiarity". Other positive remarks included the following: "Directors who serve on many boards have a broad range of experience and they can apply their learning from other boards to your company" and "you are tapping into one source with multiple points of reference [multi- 
boarded director] into the economy, [and] into different industries". Sarkar and Sarkar (2009) confirmed that interlocked directors could expand their access to social networks. Field et al. (2013) furthermore acknowledged that overboarded directors are often more experienced and better connected than their counterparts who serve on fewer boards.

The view was also raised that overboarded directors are not by implication unprepared for meetings and do not necessarily give insufficient attention to corporate matters, as suggested by the busyness hypothesis. An interviewee remarked: "I have seen non-executive directors who serve on many boards contribute to our board the most in the past. The first impression might have been that the individual served on too many boards, how is he possibly going to add value to our board? The reality has turned out to be the opposite". She concluded that "it depends from individual to individual as to how committed, focused and professional they are. Some people would self-manage whether they are overboarded or not". Overboardedness should hence be assessed on a case-by-case basis.

Another participant confirmed that companies can benefit considerably from tapping into a multi-boarded director's wealth of experience and knowledge by stating that "if something works in one company and it is efficient, it very quickly spreads across to other entities". As such, best practice could be adopted across the companies which a director represents. This participant, however, warned against "pooled thinking". Colaco et al. (2011) also cautioned against so-called groupthinking, arguing that board heterogeneity enhances decision-making by increasing access to multiple points of view. As boards become more diverse, the propensity of directors thinking and acting in the same way diminishes.

Four participants were of the opinion that overboardedness would not have a negative impact on financial performance. They mainly based their view on the perceived competencies of the executive team. One of the participants believed that "the day-to-day running of the company is handled by the executive directors, so you would expect them to be prudent". Another participant summarised the possible benefits related to director interlocking as follows: "I think the concept of serving on more than one board is a positive one but certainly once it goes beyond a point where you can really put the effort in, then it becomes a problem". Negative outcomes as postulated by the busyness hypothesis might then arise.

\section{Directors' views on the busyness hypothesis}

As explained earlier, the busyness hypothesis postulates that multi-boarded directors could become overcommitted and could find it difficult to give sufficient attention to all their board responsibilities (Clements et al. 2015). In line with this hypothesis, one participant went as far to say that "if you have a board full of overboarded directors you are on a sure road to disaster". He added that "in most cases you would not have more than two or three [overboarded members] on a board in which case the other directors often carry the board".

Considering their responses, it was evident that the participants' largest concerns pertaining to overboardedness were excessive time commitments and insufficient meeting attendance. A participant mentioned that by serving on too many boards, it might be challenging to "apply your mind", while another director said that "as soon as you see someone with a poor attendance record that would be a very big red flag". Jiraporn et al. (2009a) confirmed that board members who hold multiple positions at the same time have a tendency to miss board meetings.

Some participants furthermore cautioned against agreeing to serve on several challenging board committees, particularly audit committees. A participant remarked that "audit committees require a lot of work and if you do not spend the time going carefully through the papers you are not going to ask the right questions; you are not going to engage with the management or the internal or external audit and you run a severe risk of not actually doing your job". These views are supported by the findings of Jiraporn et al. (2009b) that an increase in overboardedness decreases the likelihood of a director serving on compensation and audit committees.

The participants also pointed out that it was challenging for them to coordinate diaries to accommodate several board and committee meetings. Board meetings are typically scheduled annually in advance and attempts are made to resolve issues. Unavoidable clashes might, however, negatively affect attendance records. A participant remarked that "for the most common board meeting months, those people [directors holding multiple board positions] are being stretched immensely".

A counterpart argued that attendance fees encouraged directors not to miss meetings. He explained that board meeting attendance are "usually extremely high, but we all know that you are not a director for $3 \mathrm{~h}$, four times a year; you are a director every single day of the year. So based on attendance, I do not think it impacts attendance because the calendar is agreed a year before the time". He continued by saying "whether directors sit on five boards or 20 boards they all coordinate their calendars and they make sure they attend because that is the thing that is being recorded. Also the JSE is on a drive to say no to annual retainer fees. So with a per attendance fee, directors are attending".

In line with the busyness theory, the majority of the interviewees indicated that overboardedness might indeed contribute to poor corporate governance. Participants 
added that the quality of meeting preparation and directors' willingness to stay updated, however, diminished the negative impact of overboardedness on corporate governance. Although some international researchers (Kaczmarek et al. 2014; Fich and Shivdasani 2006) reported that boards with many busy directors were associated with insufficient corporate governance and ultimately poor financial performance, Chiranga and Chiwira (2014) noted no significant association between multiple directorships and financial performance for selected South African directors over the period 2006-2012.

One of the interviewees expressed the view that experience does not necessarily mean that a director will make valuable contributions: "One could argue that experienced directors do not need to spend hours reviewing board packs, because they know what the financials look like, but that is where the risk lies". Experienced directors might become "too complacent about what they are doing".

An experienced director explained that travel requirements and industry familiarity could also play a role in the number of directorships that a director could deal with effectively. He described board meetings abroad as being "more difficult to attend" than local meetings. He was also of the opinion that a new board position would be easier to manage if it were in a familiar industry, since "a directorship in a new industry takes a fair amount of time to understand". This view is in agreement with Clements et al. (2015) who documented a decrease in corporate governance compliance when directors of small firms increased board memberships in unrelated companies.

Another theme that emerged from the data analysis centred on participants' suggestions for addressing director overboardedness in South Africa.

\section{The way forward in South Africa}

The majority of the participants acknowledged the positive change in the philosophy of the King IV Report to a more outcomes-based approach with fewer principles in comparison with King III. The King IV Report encourages directorates to apply "integrated thinking" to reflect on how the principles apply to their organisations (IoDSA 2016). Although no pertinent guidelines are offered on director overboardedness in King IV, one interviewee believed that the King Committee is inadvertently attempting to address the overboardedness issue. The King IV Report recommends that non-executive candidates should provide details regarding their professional commitments and confirm that they have enough time to fulfil their responsibilities (IoDSA 2016).

Most of the participants believed that it was challenging to make a rule that would limit the number of board positions that an individual director could hold, without considering personal and corporate circumstances. They hence opposed regulation on multiple directorships, as one director explained: "I do not think there is a magic number as it depends on the individual and the companies concerned and the board members' familiarity with the industries in which these companies are".

Recommendations pertaining to the maximum number of board positions that should be allowed differed. The opinion was raised that executives would struggle to attend to more than one or two additional board positions. The size of the company on whose board directors served was also mentioned as a determining factor: "If you take board positions at substantial [large] companies, you can maybe serve on two or three boards". Another interviewee concluded that five or six directorships could be held if the boards were small and had simple structures. Previous authors (Fich and Shivdasani 2006; Ferris et al. 2003) regarded directors overboarded if they served on more than three boards.

Five interviewees agreed that the future King V Report should include a section on directors serving on multiple boards to offer more guidance, but that it should not prescribe a specific limit. They were in favour of a principlesbased approach that allows flexibility considering each company's and director's circumstances. Participants also opposed the regulation of director interlocking, given South Africa's limited pool of eligible board candidates and the need to diversify directorates.

\section{Mechanisms to manage overboardedness}

The participants highlighted that nomination committees and board evaluations could play a significant role to manage overboardedness and to address related concerns. In line with Kiel and Nicholson (2006), the interviewees recommended that all board positions held by an individual should be discussed during board and individual director evaluations. By undertaking such regular and rigorous evaluations, directorates have a mechanism to guard against over-commitment and to address insufficient performance by individual board members (Kiel et al. 2005).

A participant explained that the results of the annual board performance reviews are presented to each director and the nomination committee. If a board member is found to be overcommitted, the issue needs to be resolved before the following re-election. Another counterpart confirmed that before recommending directors for re-election, his company's nomination committee evaluates whether these directors "are actually devoting enough time", whether they are "performing" and whether they are doing "what they are supposed to do". He regarded meeting attendance records as "hard evidence" in this regard. 
Several participants in this study agreed with Andres et al.'s (2013) suggestion that the possibility of overboardedness should be considered before nominating board candidates. One participant remarked that "possible overboardedness should be a fundamental discussion point for the nomination committee when recruiting new directors". However, the majority of interviewees reported that they had never formally discussed overboardedness during board and/or board committee meetings.

The participants also offered several recommendations to expand the talent pool in South Africa in an attempt to curb overboardedness. The responsibility of companies to take action in this regard was highlighted. Participants recommended that more formal training and education should be provided to board candidates. Suggestions were also made to elect "younger persons" to subsidiary boards and to introduce junior directorates to the boards of nonprofit organisations where they can gain experience. Junior boards are typically used in non-profit organisations, allowing young professionals to express their views and insights while being mentored (BoardAssist 2015).

The role of director recruitment agencies was also mentioned. A participant noted that these agencies were "not bringing new people to the table". Recruitment agencies could source board candidates beyond the traditional local circles, e.g. from academia and abroad. Other interviewees mentioned that professional industry associations, such as the South African Institute of Chartered Accountants and the South African Property Owners Association could introduce promising board candidates to companies. Two interviewees furthermore recommended that more business schools should offer training programmes for aspiring board candidates.

\section{Conclusions and recommendations}

The agency and resource dependence theories have been employed by previous researchers to investigate director overboardedness. The experience hypothesis predicts that director interlocking enhances companies' access to social networks, expertise and other resources. In contrast, the busyness hypothesis relates to the agency theory and postulates that overcommitted directors are not effective monitors.

Researchers in developed markets reported conflicting results on the relationship between director overboardedness and financial performance. Based on the argument that overboarded directors may become too busy to fulfil their multiple board duties, some researchers argued that overboarded directors could contribute to insufficient corporate governance and ultimately poor financial performance. Other scholars claimed that multi-boarded directors could make valuable contributions to companies and ultimately enhance their financial performance.

In line with the busyness hypothesis, the participants in this study confirmed that overboardedness was a concern for some JSE directors. They stressed the negative outcomes of overboardedness, such as becoming overcommitted and being unable to fulfil their responsibilities. Insufficient meeting attendance was also mentioned. However, the interviewees also highlighted several advantages related to the experience hypothesis. Multiboarded directors could offer invaluable advice and expand a company's access to social networks.

Some participants mentioned that a diligent individual could give sufficient attention to board responsibilities and make a valuable contribution despite serving on multiple boards. They hence argued that overboardedness should not be generalised and that such instances should be considered on a case-by-case basis. Travel requirements, experience, capabilities and industry knowledge could play an important role in determining the number of directorships that an individual can successfully manage.

Three possible reasons for overboardedness were identified, namely the limited pool of eligible directors in South Africa, board transformation targets and monetary benefits. Participants remarked that companies were competing to attract the same limited number of board candidates. They stated that regulation that limits multiple directorships might strain the ability of boards to function effectively. Such restrictions could also hamper companies' ability to diversify their boards. Interviewees furthermore mentioned that some individuals primarily accepted more board positions to benefit financially.

Participants offered several suggestions to increase the pool of eligible board candidates, including more training and education initiatives for promising, diverse candidates. Companies could allocate more time and resources to train board candidates. Recruitment agencies could also play a more prominent role in expanding the talent pool by inter alia sourcing new directors from academia and abroad. They could also invite talented directors who are ending their executive careers to continue their careers as nonexecutive directors. Such individuals could serve as mentors to inexperienced and young candidates. Board targets for ethnicity and gender diversity might further encourage companies to develop eligible individuals who could be nominated for board positions in future.

As part of the director recruitment criteria, nomination committees should scrutinise candidates' résumés to ensure that they can give sufficient attention to another board position. Directors who are perceived to be overcommitted should not be invited to serve on more boards. Nomination committees should request that a candidate step down from one or more boards. Shareholders have the ultimate 
responsibility to evaluate a nominee's ability to take on more positions before voting at shareholder meetings. Directors should be aware of their capabilities and refrain from accepting more directorships than they can manage. More boardroom discussions on overboardedness should also be encouraged. Board evaluation feedback sessions could provide valuable opportunities to assess directors' contributions and commitments and to timeously address concerns.

The literature clearly shows that having interlocked directors could be advantageous, but only up to a point. Once directors serve on too many boards simultaneously, negative outcomes could manifest. Future researchers could investigate the "tipping point" where the disadvantages of director overboardedness exceed the advantages. Semi-structured interviews could also be conducted with directors in other emerging markets to determine recurring overboardedness themes.

South Africans have come a long way in shaping the new South Africa-a country in which diversity is embraced and harnessed. However, as shown in this article, much work remains to be done to expand the pool of diverse directors. In doing so, the adverse consequences of overboardedness might be moderated.

Open Access This article is distributed under the terms of the Creative Commons Attribution 4.0 International License (http://crea tivecommons.org/licenses/by/4.0/), which permits unrestricted use, distribution, and reproduction in any medium, provided you give appropriate credit to the original author(s) and the source, provide a link to the Creative Commons license, and indicate if changes were made.

\section{References}

Ahern, K.R., and A.K. Dittmar. 2012. The changing of the boards: The impact on firm valuation of mandated female board representation. The Quarterly Journal of Economics 127(1): 137-197.

Ahn, S., P. Jiraporn, and Y.S. Kim. 2010. Multiple directorships and acquirer returns. Journal of Banking and Finance 34(9): 2011-2026.

Andres, C., I. Van den Bongard, and M. Lehmann. 2013. Is busy really busy? Board governance revisited. Journal of Business Finance and Accounting 40(9/10): 1221-1246.

Barrett, A. 2017. Age diversity within boards of directors of the S\&P 500 companies. KPMG. https://assets.kpmg.com/content/dam/ kpmg/jm/pdf/FINAL-Age-Diversity-Study-March-2017.pdf. Accessed 4 April 2018.

Barron, C. 2018. Activist Theo Botha on why Steinhoff's shadow falls on King codes. Sunday Times, 18 February. https://www. pressreader.com/south-africa/sunday-times/20180218/ 282578788516137. Accessed 18 February 2018.

Barry, H. 2014. Botha uphappy about Matlare's many hats. The Citizen, 16 April. https://citizen.co.za/uncategorized/161252/ botha-uphappy-about-matlares-many-hats/. Accessed 1 April 2015.
BoardAssist. 2015. Top 9 tips for managing your junior board, 20 October. https://boardassist.org/blog/top-9-tips-managingjunior-board/. Accessed 5 April 2017.

Bohman, L. 2010. Director interlocking and firm ownership. Doctoral dissertation, Stockholm University, Sweden.

Braun, V., and V. Clarke. 2006. Using thematic analysis in psychology. Qualitative Research in Psychology 3(2): 77-101.

Carpenter, M.A., and J.D. Westphal. 2001. The strategic context of external network ties: Examining the impact of director appointments on board involvement in strategic decision making. Academy of Management Journal 4(4): 639-660.

Chen, C.-W. 2008. Two essays on multiple directorships. Ph.D. dissertation, University of South Florida, Florida, United States of America.

Chiranga, N., and O. Chiwira. 2014. Impact of multiple directorships on performance for companies listed on the Johannesburg Stock Exchange (JSE). Economics World 2(6): 378-387.

Clements, C., J.D. Neill, and P. Wertheim. 2015. Multiple directorships, industry relatedness, and corporate governance effectiveness. Corporate Governance: The International Journal of Business in Society 15(5): 590-606.

Clutterbuck, D., and D. Megginson. 1999. Mentoring executives and directors. Boston, MA: Routledge.

Colaco, H.M.J., P. Myers, and M.R. Nitkin. 2011. Pathways to leadership: Board independence, diversity and the emerging pipeline in the United States for women directors. International Journal of Disclosure and Governance 8(2): 122-147.

Davies, E.M. (2015) Improving the gender balance on British boards. https://www.gov.uk/government/uploads/system/uploads/attach ment_data/file/482059/BIS-15-585-women-on-boards-daviesreview-5-year-summary-october-2015.pdf. Accessed 5 February 2017.

Ferris, S.P., M. Jagannathan, and A.C. Pritchard. 2003. Too busy to mind the business? Monitoring by directors with multiple board appointments. The Journal of Finance 58(3): 1087-1112.

Fich, E.M., and A. Shivdasani. 2006. Are busy boards effective monitors? The Journal of Finance 61(2): 689-724.

Field, L., M. Lowry, and A. Mkrtchyan. 2013. Are busy boards detrimental? Journal of Financial Economics 109(1): 63-82.

Financial Reporting Council. 2016. The UK Corporate Governance Code. https://www.frc.org.uk/getattachment/ca7e94c4-b9a949e2-a824-ad76a322873c/UK-Corporate-Governance-CodeApril-2016.pdf. Accessed 8 March 2018.

Ghosh, S. 2007. Board diligence, director busyness and corporate governance: An empirical analysis for India. Review of Applied Economics 3(1/2): 91-104.

Hafsi, T., and G. Turgut. 2013. Boardroom diversity and its effect on social performance: Conceptualization and empirical evidence. Journal of Business Ethics 112(3): 463-479.

Haniffa, R., and M. Hudaib. 2006. Corporate governance structure and performance of Malaysian listed companies. Journal of Business Finance and Accounting 33(7/8): 1034-1062.

Harris, I.C., and K. Shimizu. 2004. Too busy to serve? An examination of the influence of overboarded directors. Journal of Management Studies 41(5): 775-798.

Hill, C., and B. McDonnell. 2013. Reconsidering board oversight duties after the financial crisis. University of Illinois Law Review 3: 859-879.

Hillman, A.J., A.A. Cannella, and R.L. Paetzold. 2000. The resource dependence role of corporate directors: Strategic adaptation of board composition in response to environmental change. Journal of Management Studies 37(2): 235-256.

Inoxico. 2013. The Inoxico Director Singularity Index: Research Report. http://www.ey.com/Publication/vwLUAssets/The_Inox ico_Director_Singularity_Index_-_2013_Research_Report/ \$FILE/Innoxico.pdf. Accessed 4 April 2018. 
Institute of Directors in Southern Africa (IoDSA). 2009. King III Report on governance for South Africa. http://c.ymcdn.com/ sites/www.iodsa.co.za/resource/resmgr/king_iii/King_Report_ on_Governance_fo.pdf. Accessed 4 April 2018.

Institute of Directors in Southern Africa (IoDSA). 2016. King IV Report on corporate governance for South Africa. https://c. ymcdn.com/sites/www.iodsa.co.za/resource/resmgr/king_iv/ King_IV_Report/IoDSA_King_IV_Report_-_WebVe.pdf. Accessed 5 April 2018.

Institutional Shareholder Services (ISS). 2017. United States summary proxy voting guidelines-2017 benchmark policy recommendations. https://www.issgovernance.com/file/policy/2017us-summary-voting-guidelines.pdf. Accessed 16 April 2018.

Iturriaga, F.J.L., and I.M. Rodríguez. 2014. Boards of directors and firm performance: the effect of multiple directorships. Spanish Journal of Finance and Accounting 43(2): 177-192.

Jackling, B., and S. Johl. 2009. Board structure and firm performance: Evidence from India's top companies. Corporate Governance: An International Review 17(4): 492-509.

Jensen, M.C., and W.H. Meckling. 1976. Theory of the firm: Managerial behavior, agency costs and ownership structure. Journal of Financial Economics 3(4): 305-360.

Jiraporn, P., W. Davidson, P. DaDalt, and Y. Ning. 2009a. Too busy to show up? An analysis of director's absences. Quarterly Review of Economics and Finance 49(3): 1159-1171.

Jiraporn, P., M. Singh, and C.I. Lee. 2009b. Ineffective corporate governance: Director busyness and board committee memberships. Journal of Banking and Finance 33(5): 819-828.

Johannesburg Stock Exchange (JSE). 2017. JSE listing requirements. https://www.jse.co.za/content/JSERulesPoliciesandRegulationI tems/JSE\%20Listings\%20Requirements.pdf. Accessed 11 April 2018.

Kabi, M.M. 2015. Shareholder activism in South Africa: The directors' perspective. MBA research report, Gordon Institute of Business Science, University of Pretoria, South Africa.

Kaczmarek, S., S. Kimino, and A. Pye. 2014. Interlocking directorships and firm performance in the highly regulated sectors: The moderating impact of board diversity. Journal of Management and Governance 18(2): 347-372.

Katz, D.A., and L.A. McIntosh. 2016. So you're thinking of joining a public company board. New York Law Journal, 28 January. https://www.law.com/newyorklawjournal/almID/ 1202748104407/?slreturn=20180311044216. Accessed 12 April 2018.

Kiel, G.C., and G.J. Nicholson. 2006. Multiple directorships and corporate performance in Australian listed companies. Corporate Governance: An International Review 14(6): 530-546.

Kiel, G.C., G.J. Nicholson, and M.A. Barclay. 2005. Board, director and $C E O$ evaluation. Sydney: McGraw-Hill.

Kim, N., and E. Kim. 2015. Board capital and exploration: From a resource provisional perspective. Management Decision 53(9): 2156-2174.

Lamb, N.H. 2017. Does the number of interlocking directors influence a firm's financial performance? An exploratory meta-analysis. American Journal of Management 17(2): 47-57.

Lee, K.-W., and C.-F. Lee. 2014. Are multiple directorships beneficial in East Asia? Accounting and Finance 54(3): 999-1032.

Liu, C., and D.L. Paul. 2015. A new perspective on director busyness. The Journal of Financial Research 38(2): 193-217.
Lu, W., and A. Melin. 2016. The best and worst countries to be a rich CEO. Bloomberg, 16 November. https://www.bloomberg.com/ news/articles/2016-11-16/ranking-where-to-work-to-be-a-richceo-or-richer-than-neighbors. Accessed 21 September 2017.

Mans-Kemp, N., and S. Viviers. 2015. Investigating board diversity in South Africa. Journal of Economic and Financial Sciences 8(2): 392-414.

Mizruchi, M.S., and L.B. Stearns. 1988. A longitudinal study of the formation of interlocking directorates. Administrative Science Quarterly 33(2): 194-210.

National Association of Corporate Directors. 2015. 2015-2016 National Association of Corporate Directors Public Company Governance Survey. https://www.nacdonline.org/Store/Product Detail.cfm?ItemNumber=19733. Accessed 16 April 2018.

Nyirenda, M. 2010. Board composition in companies listed on the Johannesburg Stock Exchange. Masters dissertation, University of Pretoria, South Africa.

Oehmichen, J., D. Braun, M. Wolff, and T. Yoshikawa. 2017. When elites forget their duties: The double-edged sword of prestigious directors on boards. Journal of Management Studies 54(7): $1050-1107$.

Orol, R. 2016. Overboarded directors at Valeant, Yahoo! and elsewhere struggle with activists, M\&A. The Street, 12 August. https://www.thestreet.com/story/13673846/1/overboarded-direc tors-at-valeant-yahoo-and-elsewhere-struggle-with-activists-mamp-a.html. Accessed 12 April 2018.

Pfeffer, J., and G.R. Salancik. 1978. The external control of organizations: A resource dependence perspective. New York, NY: Harper and Row.

Roudaki, J., and M.B.U. Bhuiyan. 2015. Interlocking directorship in New Zealand. Australasian Accounting, Business and Finance Journal 9(3): 45-58.

Ruigrok, W., S. Peck, S. Tacheva, P. Greve, and Y. Hu. 2006. The determinants and effects of board nomination committees. Journal of Management and Governance 10(2): 119-148.

Sarkar, J., and S. Sarkar. 2009. Multiple board appointments and firm performance in emerging economies: Evidence from India. Pacific-Basin Finance Journal 17(2): 271-293.

Spencer Stuart. 2017. Spencer Stuart U.S. board index. https://www. spencerstuart.com/ /media/ssbi2017/ssbi_2017_final.pdf?la= en. Accessed 12 April 2018.

Williams, J.J., J. Deodutt, and J. Stainbank. 2016. An analysis of director interlocks on the Johannesburg Stock Exchange. South African Journal of Accounting Research 30(2): 120-138.

Dr Nadia Mans-Kemp is an academic in the Department of Business Management at Stellenbosch University, South Africa. Her research centres on different aspects of corporate governance, including board diversity, executive remuneration and corporate reporting.

Prof Suzette Viviers is an academic in the Department of Business Management at Stellenbosch University, South Africa. Her research centres on different aspects of corporate governance and responsible investing, including board diversity, executive remuneration and shareholder activism.

Ms Sian Collins was a post-graduate student in the Department in 2017. 